\title{
Work Fatigue based on Workload and Calories Intake in Several Food Makers
}

\section{Kelelahan Kerja berdasarkan Beban Kerja dan Asupan Kalori pada Berbagai Pembuat Makanan}

\author{
Shinta Arta Mulia \\ Double Degree Program Masters in Occupational Health and Safety and Master of International Public \\ Health, Universitas Airlangga \\ Campus C Mulyorejo, Surabaya, East Java, Indonesia 60115
}

\begin{abstract}
Introduction: Fatigue is believed as a common problem that is often encountered by workers including food makers in home industry. Fatigue is caused by various factors such as nutritional status, calories intake and workload. This study is intended to identify the correlation between caloric intake, and workload with fatigue on workers who work at home industry of sumpia, bidaran and tempe in Surabaya. Metods: This study was an observational study with cross sectional design. The samples of this study were all workers in Sinar Kencana Rangkah Home Industry, Sinar Kencana Lebak Jaya Home Industry and Bu Slamet Home Industry in Surabaya. Data were collected by measuring food recall 24 hours, measuring workload, and using questioner of fatigue. Data were presented on the table then were analyzed using Spearman Correlation Test. Results: The result showed that there were correlations between caloric intake (correlation coefficient: 0,530), and workload (correlation coefficient: 0.939) with work fatigue. Conclusion: The lesser the calories intake of the workers, the more severe the work fatigue experienced. The heavier the workload given to the workers, the more severe the work fatigue underwent by the workers.
\end{abstract}

Keywords: caloric intake, food maker, home industry, workload, work fatigue

\begin{abstract}
ABSTRAK
Pendahuluan: Kelelahan kerja dapat dikatakan sebagai permasalahan umum yang sering dijumpai pada tenaga kerja, termasuk pekerja pembuat makanan di home industry. Kelelahan pekerja home industry pembuat makanan tersebut dapat terjadi karenan beberapa faktor antara lain status gizi, asupan kalori dan beban kerja. Tujuan dari penelitian ini adalah untuk untuk mempelajari hubungan antara asupan kalori, dan beban kerja dengan kelelahan kerja pada pekerja di tiga home industry di Surabaya yaitu di home industry sumpia, bidaran dan tempe. Metode: Penelitian ini merupakan penelitian observasional dengan desain cross sectional. Sampel dalam penelitian ini adalah seluruh pekerja di Home Industry Sinar Kencana Rangkah, Home Industry Sinar Kencana Lebak Jaya dan Home Industry Bu Slamet di Surabaya. Pengambilan data meliputi food recall 24 jam, pengukuran beban kerja, dan kuesioner perasaan kelelahan kerja. Analisis data yang digunakan adalah analisis univariat dan uji korelasi spearman. Hasil: Menunjukkan adanya hubungan antara asupan kalori (koefisien 0,530), dan beban kerja (koefisien 0,939) dengan kelelahan kerja. Simpulan: Semakin sedikit asupan kalori pekerja, semakin parah tingkat kelelahan kerja. Semakin berat beban kerja yang diberikan kepada pekerja, semakin parah kelelahan kerja yang dialami oleh pekerja.
\end{abstract}

Kata kunci: asupan kalori, beban kerja, home industry, kelelahan kerja, pembuat makanan

\section{Corresponding Author:}

Shinta Arta Mulia

Email: shintaarta21@gmail.com 


\section{INTRODUCTION}

Workers are every individual who is able to work with the intention to produce goods or services that are beneficial to fulfill personal and community needs (President of the Republic of Indonesia, 2003). The existence of workers is one of the factors that can support the development and the establishment of a country. Other than that, workers can also support the economic development of a country; thus, healthy, productive, and qualified workers are essential.

The term worker does not only refer to those who work in formal sectors like industry, but also to those who work in informal sectors. One of the informal sectors that can frequently be found in society is small industries or home industries. Home industry is a term to describe the economic activity run by a person in her/his residence or house. In other words, a home industry can be declared as both a residence and a workplace.

The production process in the home industry tends to use minimal equipment and is still in need of workers to operate the equipment. In line with that, it can be presumed that the running of the production process in a home industry depends on the workers. Therefore, the endeavor to maintain the well-being of the workers to sustain the productivity and quality of the workers as well as to uphold the health and the safety of the workers are indeed indispensable.

The endeavor of occupational health is objectified to protect the workers that they can live healthily and unburden of health issues as well as negative influences caused by the work. One of the health problems encountered by the workers is work fatigue. Work fatigue is one of many problems noticed on the workers.

Fatigue is a body protection mechanism. The protection mechanism itself aims to prevent the body from additional damages by recovering after resting (Sari, 2014). Fatigue is likely to be indicated by exhaustion, wearied, muscle tension, and low energy levels.

Work fatigue has negative impacts on its sufferers. Work fatigue can increase the possibility of errors in doing works. Likewise, work fatigue can also decrease the working performance of a worker. Work fatigue is usually depicted as a state in which the efficiency, performance, and strength, as well as physical endurance of the body in doing activities, diminish (Ramayanti, 2015).

Every kind of work will result in work fatigue (Rambulangi, 2016). The level of work fatigue experienced by workers is dissimilar. The unlike level of work fatigue is based on the work type and working hour. Work fatigue is influenced or triggered by several factors. According to Ramayanti (2015), there are 2 factors that influence the occurrence of work fatigue, namely internal and external factors. The internal factors that are likely to cause work fatigue are age, nutrition status, sex, knowledge, years of service, and lifestyle. In the meantime, the external factors that initiate work fatigue are working environment and other work factors, such as workload, work shifts, working hours, break duration, work attitudes, and monotonous conditions.

Work fatigue suffered by the workers are different from one another, depending on the workload received by the workers themselves. The workload is an interaction between the demands of tasks, working environment, skills, behavior, and perceptions of workers (Maharja, 2015).

Other than that, the complaints of work fatigue can also be triggered by the additional workloads handed to the workers in the form of work climate. Generally speaking, the work climate describes a hot work climate. The production process in one industry habitually needs a heat source. The heat from the production process is exposed to the working environment, resulting in the increase in temperature in the workplace. A workplace with high temperature will be perceived as an additional workload by the workers (Ramayanti, 2015).

The workers who work in a home industry are expected to carry out a series of production processes manually. The production process in a home industry that is completed without the support from sophisticated machines transforms into a workload for the workers. Additionally, the workers in a home industry, particularly those who engaged in the food sector also acquire an additional workload from the hot working climate. The addition of workloads can be happened providing home industry needs heat sources to continue the production process, which results to the workers do their jobs in the working environment that has already exposed to the heat source. 
Home industry owned by Mrs. Wati is an industry in the sector of snack production called sumpia in Surabaya. Almost all of the activities in the production process are performed by the workers, such as making the sumpia wrappers, putting in the fillings, and frying the sumpia.

Mrs. Wati also owns a home industry that produces bidaran. Similar to sumpia home industry, nearly all production process of bidaran is done manually. However, the shaping of bidaran is the only process finished by using a pressing machine. Even so, the pressing of the dough still needs human powers in its operation. Furthermore, the process of frying bidaran is also done manually by the workers.

Similar to the previous home industries, the home industry that produces tempe in Wonocolo Surabaya also completes the series of production processes manually. All activities to make tempe, begins with washing, soaking, peeling, boiling soybeans, to the provision of yeast and packaging in this home industry have not yet been modernized.

The things occur during the production process to the packaging in those three food home industries are strongly believed to trigger work fatigue of the workers. The likelihood of work fatigue of the workers in those home industries is the background of the study concerning work fatigue. This study aims to describe the level of work fatigue based on the workload and work climate on the workers in three home industries in Surabaya.

\section{METHODS}

This study is an observational study since it only performs observation without giving intervention or treatment to the subjects of the study. Reflected on the data analysis, this study is a descriptive study since this study is conducted to depict or describe an occurrence or condition in a particular population. This study implements a cross-sectional design providing the data collection is done in a certain period of time.

This research was conducted from January to August 2017 by involving three home industries in Surabaya. Those three home industries engage in the field of food production, namely sumpia, bidaran, and tempe. The subjects of this study were the total population or the whole workers in the mentioned home industries. The total population of sumpia home industry was 17 workers, while bidaran home industry had the total population of 10 workers, and tempe home industry with 14 workers.

There were two variables of this study, namely dependent and independent variables. The dependent variable was work fatigue. Meanwhile, calories intake and workload were the independent variables. The data of this study was the primary data gathered by conducting interview and measurement.

The data collection regarding calories intake of each worker was completed by carrying out an interview on the food every one of them consumed for the past 24 hours (food recall 24 hours). After all of the data had been assembled, it was then treated by using an application known as Nutrisurvey. The application showed the number of workers' calories intake for a day.

The interview was accomplished to collect data regarding work fatigue suffered by the workers (subjective feelings of fatigue). To explain more, the interview was completed by reading a questionnaire on the measurement of work fatigue of the workers. The questionnaire consisted of 30 questions; 10 questions asked about weakening activities, 10 questions on weakening motivations, and 10 questions concerning on weakening motivations.

The measurement was ensured to gather the data regarding workload. To be noted, the workload measured in this study is the physical workload. In broad, the measurement of physical workload was performed by applying calorimeter. The calorimeter was worn on the workers' wrist for four hours.

After the data collection has been completed, the data was then analyzed by implementing univariate and bivariate analysis. The univariate analysis was carried out to obtain the big picture of the distribution on the frequency of the workers regarding their individual characteristics (sex, age, years of service, and nutritional status), calories intake, workload, and work fatigue. On the other hand, the bivariate analysis was executed by implementing the spearman correlation statistical test. The statistical test was completed to figure out the relationship between dependent variables, namely workload 
and calories intake, and independent variables, such as work fatigue.

\section{The Characteristics of the Respondents}

Table 1. The Distribution of the Respondents' Characteristics on the Workers of Sumpia, Bidaran, and Tempe Home Industries in Surabaya

\section{RESULT}

workers, with the percentage of $14.6 \%$ and $9.8 \%$, respectively.

Similar to bidaran home industry, the male workers in tempe home industry also outnumbered the female workers. It was noticed that $19.5 \%$ of the workers in tempe home industry were male and $14.6 \%$ were female.

\section{Age of the Respondents}

The findings of the study presented that the number of workers with the ages of $21-40$ years old is bigger than the workers with the ages of 41 -60 years old is. In addition, the number of the

\begin{tabular}{|c|c|c|c|c|c|c|c|c|}
\hline \multirow{2}{*}{$\begin{array}{l}\text { Respondents' } \\
\text { Characteristics }\end{array}$} & \multicolumn{2}{|c|}{ Sumpia } & \multicolumn{2}{|c|}{ Bidaran } & \multicolumn{2}{|c|}{ Tempe } & \multicolumn{2}{|c|}{ Total } \\
\hline & $\mathbf{n}$ & $\%$ & $\mathbf{n}$ & $\%$ & $\mathbf{n}$ & $\%$ & $\mathbf{N}$ & $\%$ \\
\hline \multicolumn{9}{|l|}{ Sex } \\
\hline Male & 1 & 2,4 & 6 & 14,6 & 8 & 19,5 & 15 & 36,6 \\
\hline Female & $\begin{array}{l}1 \\
6\end{array}$ & 39,0 & 4 & 9,8 & 6 & 14,6 & 26 & 63,4 \\
\hline \multicolumn{9}{|l|}{ Age } \\
\hline $21-40$ years old & 8 & 19,5 & 8 & 19,5 & $\begin{array}{l}1 \\
3\end{array}$ & 31,7 & 29 & 70,7 \\
\hline $41-60$ years old & 9 & 22,0 & 2 & 4,9 & 1 & 2,4 & 12 & 29,3 \\
\hline \multicolumn{9}{|l|}{ Years of Service } \\
\hline $0-5$ years & 8 & 19,5 & 3 & 7,3 & 4 & 9,8 & 15 & 36,6 \\
\hline $6-10$ years & 3 & 7,3 & 6 & 14,6 & 6 & 14,6 & 15 & 36,6 \\
\hline$>10$ years & 6 & 14,6 & 1 & 2,4 & 4 & 9,8 & 11 & 26,8 \\
\hline \multicolumn{9}{|l|}{$\begin{array}{l}\text { Nutritional } \\
\text { Status }\end{array}$} \\
\hline Mild Thinness & 4 & 9,8 & 2 & 4,9 & 1 & 2,4 & 7 & 17,1 \\
\hline Normal & 8 & 19,5 & 5 & 12,2 & $\begin{array}{l}1 \\
0\end{array}$ & 24,4 & 23 & 56,1 \\
\hline Overweight & 4 & 9,8 & 3 & 7,3 & 3 & 7,3 & 10 & 24,4 \\
\hline Obese & 1 & 2,4 & 0 & 0 & 0 & 0 & 1 & 2,4 \\
\hline
\end{tabular}

Referring to the results of the study, it was obtained that the data were in form of the respondents' characteristics, for instance, sex, age, years of service, and nutritional status. The distribution of the respondents' characteristic can be comprehended by examining the following table 1 .

\section{Sex of the Respondents}

The results of the study disclosed that the number of female workers is greater than the number of the male workers with the percentage of $63.4 \%$ of female workers and $36.6 \%$ of male workers.

The majority of the workers in sumpia home industry was female workers with a percentage of $39.0 \%$, which outnumbered $2.4 \%$ of male workers.

In contrast, bidaran home industry has more of male workers compared to female workers with the ages of $21-40$ years old reached $70.7 \%$, while the workers ranged from the age 41 60 years old attained the percentage of $24.4 \%$.

The majority of the workers in sumpia home industry are those with the age range from $41-60$ years old with a percentage of $22 \%$. Meanwhile, the same home industry, sumpia home industry, had only $19.5 \%$ of workers ranging from the age of $21-40$ years old.

Different from the number of the workers in sumpia home industry, the ones in bidaran home industry had more with the ages of $21-40$ years old compared to the workers with the ages of $41-$ 60 years old. $19.5 \%$ of the workers in bidaran home industry was noticeably ranging from the ages of $21-40$ years old. Meanwhile for the rest, $4.9 \%$ of the workers ranging from the ages of $41-$ 60 years old.

The percentages discovered on bidaran home industry was similar with the percentages of the workers in tempe home industry, where the workers with the ages of $21-40$ years old outnumbered the workers with the ages of $41-60$ years old. In addition, there were $31.7 \%$ workers aging from 21 - 40 years old working in tempe home industry, while for the workers with the ages of $41-60$ years old, the percentage was $2.4 \%$.

\section{Years of Service of the Respondents}

The results of the study displayed that the majority of the workers had been working for 0 5 years and $6-10$ years. The percentage of the workers who had been working for $0-5$ years was $36.6 \%$, while the percentage of those who had been working for $6-10$ years was $36.6 \%$. In addition, the workers who had been working for 
more than 10 years $(>10$ years $)$ reached a percentage of $26.8 \%$.

Almost all workers working in sumpia home industry were noted had been working for 0 - 5 years, which was about $19.5 \%$. In the meantime, the workers working in sumpia home industry who had been working for $6-10$ years and more than 10 years had the percentages of $7.3 \%$ and $14.6 \%$, respectively.

Nearly all of bidaran home industry workers who had been working for 6 to 10 years were spotted for about $14.6 \%$, followed by those who had been working for less than 5 years with the percentage of $7.3 \%$. In addition, only $2.4 \%$ of workers in bidaran home industry were perceived working for more than 10 years.

Akin to bidaran home industry, the majority of the workers in tempe home industry with the years of service for $6-10$ years reached $14.6 \%$. Additionally, the workers who had been working for less than 5 years and more than 10 years had a percentage of $9.8 \%$ each.

\section{Nutritional Status of the Respondents}

The results of the study elucidated the distribution of the workers based on their nutritional status. The workers in all three home industries tended to have normal nutritional status, consisting of 23 workers $(56.1 \%)$. Other than that Low the workers that belong to mild thinness Moderate nutritional status were 7 people (17.1\%), while Good those with overweight nutritional status reached Total the number of 10 (24.4\%), followed by the onlyworker with obese nutritional status $(2.4 \%)$.

The workers in sumpia home industry were more likely to have normal nutritional status, which was $19.5 \%$. Meanwhile, the workers with mild thinness nutritional status reached a percentage of $9.8 \%$. Interestingly, the percentage was similar to the percentage of the workers in sumpia home industry with overweight nutritional status. Additionally, there were $2.4 \%$ of the workers in sumpia home industry who had obese nutritional status.

Similar to sumpia home industry, the workers in bidaran home industry managed to have normal nutritional status, which attained the percentage of $12.2 \%$. However, $4.9 \%$ of them were discovered having mild thinness nutritional status and $7.3 \%$ of all workers in bidaran home industry have overweight nutritional status. Even so, there was no worker noticed with obese nutritional status.

Similar to the previous two home industries, the majority of the workers' nutritional status in tempe home industry was realized to be normal, with a percentage of $24.4 \%$. Among all workers in tempe home industry, $7.3 \%$ were ascertained to have overweight nutritional status. In addition, $4.9 \%$ of the workers in the industry have mild thinness nutritional status. Furthermore, same as the condition in bidaran home industry, there was no single worker in tempe home industry spotted having obese nutritional status.

\section{Calories Intake of the Respondents}

According to the results of the study, the data concerning the calories intake of the workers of sumpia, bidaran, and tempe home industries were discovered. The data distribution can be seen in Table 2.

Table 2. The Distribution of Calories Intake on the Workers of Sumpia, Bidaran, and Tempe Home Industries in Surabaya

\begin{tabular}{lcccccccc}
\hline \multirow{2}{*}{$\begin{array}{l}\text { Calories } \\
\text { Intake }\end{array}$} & \multicolumn{2}{c}{ Sumpia } & \multicolumn{2}{c}{ Bidaran } & \multicolumn{2}{c}{ Tempe } & \multicolumn{2}{c}{ Total } \\
\cline { 2 - 9 } & $\mathbf{n}$ & $\boldsymbol{\%}$ & $\mathbf{n}$ & $\boldsymbol{\%}$ & $\mathbf{n}$ & $\boldsymbol{\%}$ & $\mathbf{N}$ & $\%$ \\
\hline Low & 5 & 12,2 & 4 & 9,8 & 7 & 17,1 & 16 & 39,0 \\
Moderate & 5 & 12,2 & 3 & 7,3 & 4 & 9,8 & 12 & 29,3 \\
Good & 7 & 17,1 & 3 & 7,3 & 3 & 7,3 & 13 & 31,7 \\
\hline Total & 17 & 41,5 & 10 & 24,4 & 14 & 34,1 & 41 & 100 \\
\hline
\end{tabular}

The results disclosed that the workers were likely to have low calories intake, which was about $39.0 \%$. Meanwhile, the workers with moderate calories intake amounted to $29.3 \%$. As for the rest, $31.7 \%$, it belonged to those who have good calories intake. To be precise, there were no workers discovered with deficit amount of calories intake.

Bestowing to the results of the study, the workers in sumpia home industry had good calories intake, with the percentage of $17.1 \%$, while those with low calories intake were noticed reaching the percentage of $12.2 \%$. The number was similar to the number of the workers of sumpia home industry who had moderate calories intake. 
The workers in bidaran home industry were more likely discerned having low calories intake $(9.8 \%)$. Meanwhile, the workers with moderate nutritional intake reached a percentage of $7.3 \%$. The number of the percentage was the same as the number of workers of bidaran industry with good calories intake.

The workers of tempe home industry have a similarity in terms of calories intake with the workers of bidaran home industry. If elaborated, the workers of tempe home industry, as much as $9.8 \%$, had moderate calories intake and the rest, $7.3 \%$, had good calories intake.

\section{The Workload of the Respondents}

Giving the results of the study, the data in form of physical workload given to the workers of sumpia, bidaran, and tempe home industries were obtained. Table 3 presents that the workers were more likely to have a moderate workload, as much as $56.1 \%$. In the meantime, the workers with low workload were as much as $36.3 \%$ and those with heavy workload was as much as $73.0 \%$. The distribution of the workload can be perceived from the following table 3 .

Table 3. The Distribution of Physical Workload of the Workers of Sumpia, Bidaran, and Tempe Home Industries in Surabaya

\begin{tabular}{lcccccccc}
\hline \multirow{2}{*}{ Workload } & \multicolumn{2}{c}{ Sumpia } & \multicolumn{2}{c}{ Bidaran } & \multicolumn{2}{c}{ Tempe } & \multicolumn{2}{c}{ Total } \\
\cline { 2 - 9 } & $\mathbf{n}$ & $\boldsymbol{\%}$ & $\mathbf{n}$ & $\boldsymbol{\%}$ & $\mathbf{n}$ & $\boldsymbol{\%}$ & $\mathbf{N}$ & $\boldsymbol{\%}$ \\
\hline Low & 8 & 19,5 & 3 & 7,3 & 4 & 9,8 & 15 & 36,3 \\
Moderate & 9 & 22,0 & 6 & 14,6 & 8 & 19,5 & 23 & 56,1 \\
Heavy & 0 & 0 & 1 & 2,4 & 2 & 4,9 & 3 & 7,3 \\
\hline Total & 17 & 41,5 & 10 & 24,4 & 14 & 34,1 & 41 & 100 \\
\hline
\end{tabular}

Referring to the results of the study, the workers of sumpia home industry tended to have a moderate workload, with the percentage of $22.0 \%$. Other than that, some of the workers, as much as $14.6 \%$, had a moderate workload in bidaran home industry. The workers of tempe home industry had similarities to the workers in bidaran home industry seen from their workload. The workers of tempe home industry tended to experience moderate workload, as much as $19.5 \%$.
There were no workers of sumpia home industry experienced heavy workload. On the other hand, in two other home industries, the workers with heavy workload were discovered. In fact, there were $2.4 \%$ of the workers of bidaran

\begin{tabular}{|c|c|c|c|c|c|c|c|c|}
\hline \multirow{3}{*}{ Variable } & \multicolumn{4}{|c|}{ Work Fatigue } & & & \multirow{2}{*}{\multicolumn{2}{|c|}{ Total }} \\
\hline & \multicolumn{2}{|c|}{ Low } & \multicolumn{2}{|c|}{ Moderate } & \multicolumn{2}{|c|}{ Good } & & \\
\hline & $\mathbf{n}$ & $\%$ & $\mathbf{n}$ & $\%$ & n & $\%$ & $\mathbf{n}$ & $\%$ \\
\hline \multicolumn{9}{|l|}{ Calories } \\
\hline Intake & 2 & 4,9 & 13 & 31,7 & 1 & 2,4 & 16 & 39,0 \\
\hline Low & 2 & 4,9 & 9 & 22,0 & 1 & 2,4 & 12 & 29,3 \\
\hline $\begin{array}{l}\text { Moderate } \\
\text { Good }\end{array}$ & 10 & 24,4 & 3 & 7,3 & 0 & 0 & 13 & 31,7 \\
\hline Total & 14 & 34,1 & 25 & 61,0 & 2 & 4,9 & 41 & 100 \\
\hline \multicolumn{9}{|l|}{ Workload } \\
\hline Low & 14 & 34,1 & 1 & 2,4 & 0 & 0 & 15 & 36,6 \\
\hline Moderate & 0 & 0 & 23 & 56,1 & 0 & 0 & 23 & 56,1 \\
\hline Heavy & 0 & 0 & 1 & 2,4 & 2 & 4,9 & 3 & 7,3 \\
\hline Total & 14 & 34,1 & 25 & 61,0 & 2 & 4,9 & 41 & 100 \\
\hline
\end{tabular}

home industry experienced a heavy workload.

Furthermore, the workers of tempe home industry who underwent heavy workload were as much as $4.9 \%$.

\section{The Work Fatigue of the Respondents}

According to the results of the study, it was obtained the data concerning the work fatigue experienced by the workers of sumpia, bidaran, and tempe home industries. Referring to Table 4, the workers tended to experience moderate work fatigue, with the percentage of $61 \%$. Other than that, the workers with mild work fatigue were noticed as much as $34.1 \%$, followed by the workers with severe work fatigue with a percentage of $4.9 \%$.

The distribution of work fatigue underwent by the workers can be seen in Table 4. In accordance with the results obtained, the workers of sumpia home industry were most likely experiencing moderate work fatigue, as much as $24.4 \%$. Similar to the occurrence of work fatigue of the workers of sumpia home industry, those of bidaran home industry also suffered from moderate work fatigue. The percentage of the workers experiencing moderate work fatigue in bidaran home industry was $17.1 \%$. Meanwhile, the number of workers of tempe home industry who also experienced moderate work fatigue was as much as $19.5 \%$. 
Table 4. The Distribution of Work Fatigue on the Workers of Sumpia, Bidaran, and Tempe Home Industries in Surabaya

The distribution of work fatigue based on the calories intake and workload can be comprehended through Table 5.

Tabel 5. The Distribution of Work Fatigue based on the Calories Intake and Workload on the Workers of Sumpia, Bidaran, and Tempe Home Industries in Surabaya

\section{The Level of Work Fatigue Based On Calories Intake}

Referring to the results of cross-tabulation between the calories intake and work fatigue, the workers with good calories intake were most likely to experience moderate work fatigue $(31.7 \%)$. Moreover, workers with moderate calories intake tended to undergo moderate work fatigue $(22.0 \%)$. In addition, workers with good calories intake were noticed to experience mild work fatigue $(24.4 \%)$. The elucidation below explains the distribution results of the cross tabulation carried out between the calories intake of the respondents to the work fatigue in sumpia, bidaran, and tempe home industries.

The statistic test revealed the significance value $\mathrm{p}=0.0000(p$-value $<0.05)$, which indicated that there was a correlation between the calories intake and the work fatigue underwent by the workers of sumpia, bidaran, and tempe home industries in Surabaya with the correlation coefficient as much as 0.530 .

\section{The Level of Work Fatigue Based On Workload}

The results showed that the workers with low workload tended to experience mild work fatigue $(34.1 \%)$. Meanwhile, the workers with moderate workload were most likely to undergo moderate work fatigue $(56.1 \%)$. Additionally, the workers with heavy workload were noticed to suffer from severe work fatigue (4.9\%).

The statistic test disclosed that the significance value $\mathrm{p}=0.0000$ ( $p$-value $<0.05)$, signifying that there was a correlation between the workload and the work fatigue experienced by the workers of sumpia, bidaran, and tempe home industries in Surabaya with the correlation

\begin{tabular}{lcccccccc}
\hline \multirow{2}{*}{ Work } & \multicolumn{2}{c}{ Sumpia } & \multicolumn{2}{c}{ Bidaran } & \multicolumn{2}{c}{ Tempe } & \multicolumn{2}{c}{ Total } \\
\cline { 2 - 9 } Fatigue & $\mathbf{n}$ & $\boldsymbol{\%}$ & $\mathbf{n}$ & $\boldsymbol{\%}$ & $\mathbf{n}$ & $\boldsymbol{\%}$ & $\mathbf{N}$ & $\%$ \\
\hline Mild & 7 & 17,1 & 3 & 7,3 & 4 & 9,8 & 14 & 34,1 \\
Moderate & 10 & 24,4 & 7 & 17,1 & 8 & 19,5 & 25 & 61,0 \\
Severe & 0 & 0 & 0 & 0 & 2 & 4,9 & 2 & 4,9 \\
\hline Total & 17 & 41,5 & 10 & 24,4 & 14 & 34,1 & 41 & 100 \\
\hline
\end{tabular}

coefficient as much as 0.939 .

\section{DISCUSSION}

Conferring to Tarwaka (2015), work fatigue occurred due to several factors. One of the factors causing work fatigue is working activities. Workload will arise along with the working activities (Maharja, 2015). Other than that, Grandjean (1979) denoted that another reason of work fatigue is nutrition. The nutrition consumed by the workers must be in accordance with the daily needs of every worker.

The results of the study presented that the number of workers with a good amount of calories intake is less than of those with low and moderate calories intake is. The non-fulfillment of the calories of the workers can be caused by the tendency of the workers to not pay attention to diet and nutrients of the food they consume. Besides, the owners of the home industries also pay less attention to the work nutrition issues of their workers.

In addition, the results of the study indicated that the workers had the tendency to undergo moderate workload. The workers were noticed experiencing workload from the work that they have to complete manually. In fact, the food production process in home industries is still performed manually without the help from any equipment or machine. In addition, the workers with moderate workload are those who complete their work by relying on muscle power. Besides completing their main jobs, such as frying sumpia or bidaran and boiling soybean seeds, the workers are given additional works, for instance, transporting the product, be it sumpia, bidaran, or tempe, and moving the product to the next stage, namely packaging. Those additional works are given due to the different places between the production kitchen and the packaging place. 
According to the research conducted, almost all workers have a probability to suffer from work fatigue, be it in mild, moderate, or severe level. The most work fatigue level discovered in sumpia, bidaran, and tempe home industries is moderate work fatigue. The majority of workers with moderate work fatigue are those with low calories intake and moderate workload.

\section{The Level of Work Fatigue Based On Calories Intake}

Every human being needs energy to perform any activity or work. When a body is lack of energy qualitatively or quantitatively, it will bother somebody's working capacity (Maharja, 2015). The energy used when doing work is obtained by consuming calories as needed. According to Maharja (2015) the amount of calories consumed by workers plays a role in fulfilling energy so they can complete their works.

Calories intake that is not suitable both in terms of quantity and in terms of time will cause a decrease in work resistance. Furthermore, the imbalance of calories intake will slow down the working performance of a worker, resulting in the worker experiences work fatigue sooner (Sari, 2014). That claim is in accordance with the statement of Fatmawati (2015), which believed that if the calories intake in the body is less or more than the normal amount, somebody will be easier to experience work fatigue.

The results of this study showed that there is a strong correlation between calories intake and work fatigue. Other than that, this study also displayed that workers with good calories intake tend to experience mild work fatigue. On the other hand, workers with moderate calories intake and low calories intake are more likely to suffer from moderate work fatigue. The results obtained indicated that the lesser calories intake in the body, the more severe the level of work fatigue experienced by the workers. In broad, the results of this study are in accordance with the results of the study authored by Adi, Suwondo and Lestyanto (2013). Their study discovered that work fatigue is experienced more by workers with unfulfilled calories intake.

Moreover, the results of this study are in line with the results of the study conducted by (Fatmawati, 2015). Oentoro's results disclosed that people with less than normal calories intake will be easier to suffer from work fatigue due to the loss of energy.

The state in which the workers lack energy will lead to the occurrence of activities, physical work, and thought weakening (Marsetyo and Kartasapoetra, 2008). Loss of energy can have an impact on the loss of glycogen and oxygen supplies on muscle tissues, which leads to the difficulty of muscle contraction to perform activities. Referring from Maharja (2015), the muscle that works statically will obstruct blood circulation in muscle due to the pinched muscle blood vessel by the internal pressure of muscle tissue so that the muscle can only rely on the reserves of food essence in the muscle and most energy produced from the anaerobic process. One of the products of the anaerobic process is the production of ATP that can trigger the accumulation of metabolite (lactic acid) in the muscle tissues. The accumulation of lactic acid in the muscle tissues will cause the occurrence of muscle fatigue.

\section{The Level of Work Fatigue Based On Workload}

The workload is a demand for work or efforts made to complete works. Physical workload will affect the changing of the physiological function of the body (Tarwaka, 2015). Physical workload includes physical energy in human muscle that will be used as the energy source.

The results of the study indicated that there is a strong correlation between physical workload and work fatigue suffered by the workers of three home industries. That correlation implies that the more physical workload received by the workers, the more severe the work fatigued experienced by the workers. Interestingly, those results are in accordance with the results of the study conducted by Triyunita, Ekawati and Lestyanto (2013) and the study authored by Atiqoh, Wahyuni and Lestyanto (2014). High physical workload will weaken and reduce the speed of muscle contraction. Furthermore, physical workloads will affect the changes in the physiology of the body, so that additional physical workload will weaken the muscle performance that can lead to work fatigue. 
The results of this study are in line with the study conducted by Maharja (2015). Maharja's study indicated that physical workload and work fatigue have an equivalent and strong correlation. Additionally, this study is also similar to the study completed by Utami (2012), which resulted in showing the correlation between workload and work fatigue.

The works done by the workers of three home industries in Surabaya are the works that involve many physical activities. The high amount of physical activities causes physical work fatigue to the workers. According to Maharja (2015) the heavier the physical workload given, the faster the oxygen consumption to reach the maximum point. The reaching of the maximum point will cause oxygen consumption decrease and manifest that can lead to exhaustion due to the increase of lactic acid. Maharja (2015) also credited that if the physical workload is more than maximum of oxygen intake, there is going to be a decrease of oxygen supply to the muscle that triggers the division of muscle glycogen to become energy and lactic acid through an anaerobic process. The lactic acid then accumulates in the muscle that can initiate the swelling of the muscle as well as the feeling of being difficult to concentrate. Those things are believed to be the main causes of exhaustion.

\section{CONCLUSION}

According to the study that has been completed, it was noticed that there is a correlation between calories intake and work fatigue. The lesser the calories intake of the workers, the more severe the work fatigue experienced. Otherwise, the results also described that there is a correlation between workload and work fatigue. In other words, the heavier the workload given to the workers, the more severe the work fatigue underwent by the workers.

In as much as the results indicated that the workers tend to have low calories intake, it is believed that the owners of the home industries should carry out a free lunch program to the workers to fulfill the energy needed by the workers. Furthermore, to ease the workload, it will be better if the transference of the product is performed with the help of trolley.

\section{ACKNOWLEDGEMENT}

The researcher would like to thank all the respondents for their participation in the research.

\section{REFERENCES}

Adi, D. P. G. S., Suwondo, A. and Lestyanto, D. (2013) 'The Correlation between Working Climate and Nutrient Intake before Working on the Fatigue Level of the Morning Shift Workers on Packing Division of PT.X, Kendal', Jurnal Kesehatan Masyarakat FKM Undip, 2(2), pp. 1-11.

Atiqoh, J., Wahyuni, I. and Lestyanto, D. (2014) 'Factors Associated with Work Fatigue in Workers Convection Section Tailoring at CV. Aneka Garment Gunungpati Semarang', Jurnal Kesehatan Masyarakat FKM Undip, 2(2), pp. 119-126.

Fatmawati, L. (2015) Factors Associated with Work Fatigue in the Engineering Workforce Mechanical Maintenance Section (Study at PT Sinar Mas Agro Resources and Technology (SMART) Tbk Surabaya). Undergarduate Thesis. Faculty of Public Health, Universitas Airlangga.

Grandjean, E. (1979) 'Fatigue in industry', British Journal of Industrial Medicine, 36, pp. 175-186.

Maharja, R. (2015) 'Analsys of Level of Work Fatigue based on Physical Workload of the Nurses in Inpatient Care Unit of RSU Haji Surabaya', The Indonesian Journal of Occupational Safety and Health, 4(1), pp. 93-102.

Marsetyo and Kartasapoetra, G. (2008) Nutritional Sciences: Correlation of Nutrition, Health and Work Productivity. Jakarta: Rineka Cipta.

President of the Republic of Indonesia (2003) Law of the Republic of Indonesia Number 13 of 2003 Concerning Employment. Jakarta: President of the Republic of Indonesia.

Ramayanti, R. (2015) 'The Relationship between Nutritional Status and Work Climate with Work Fatigue in Hikmah Food Catering', The Indonesian Journal of Occupational Safety and Health, 4(2), pp. 177-186.

Rambulangi, C. J. (2016) 'The Relationship of 
Work Load with Fatigue of Samarinda National Land Agency Level II's Employees', Psikoborneo, 4(2), pp. 292300.

Sari, A. R. (2014) The Relationship between Body Mass Index (BMI) and Calories Consumption with Work Fatigue on Women Worker in PT Mermaid Textile (Mertex) Mojokerto. Undergraduate Thesisi. Faculty of Public Health Universitas Airlangga.

Tarwaka (2015) Industrial Ergonomics: Basics of Ergonomics Knowledge and Applications at Work. 2nd edn. Surakarta: Harapan Press.

Triyunita, N., Ekawati and Lestyanto, D. (2013)
'The Relations of the Physical Workload, Noise and Individual Factors with Worker Fatigue on Weaving part PT. X Batang', Jurnal Kesehatan Masyarakat FKM Undip, 2(2), pp. 1-11.

Utami, A. R. D. (2012) The Relationship between Workload and Noise Intensity, and the Exhaustion of the Workers of Cisalak Kotabima Road Maintenance of CV Serayu Indah Cilacap, Jurusan Ilmu Kesehatan Masyarakat Fakultas Ilmu Keolahragaan Universitas Negeri Semarang. Undergraduate Thesis. Faculty of Sport Sciences, Universitas Negeri Semarang. 